\title{
INUNDAÇÕES E VULNERABILIDADE SOCIOECONÔMICA NA ÁREA URBANA DE ERECHIM, RS (BRASIL)
}

\author{
André Ricardo Furlan ${ }^{1}$ \\ Juçara Spinelli ${ }^{2}$
}

Resumo: As inundações em áreas urbanas têm sido um grave problema, pois afeta certo quantitativo populacional e causa danos, muitas vezes, irreparáveis às comunidades e aos espaços da cidade. Este trabalho apresenta uma metodologia auxiliar à identificação das áreas de perigo de inundação e à vulnerabilidade socioeconômica em um estudo na cidade de Erechim, localizada na porção norte do Rio Grande do Sul/Brasil que registra, segundo a defesa civil municipal e reportagens de jornais, significativos pontos de inundação. Os resultados foram obtidos pela análise dos pontos identificados como recorrentes de inundações em períodos de chuvas intensas e de dados socioeconômicos (renda, alfabetização, densidade demográfica e tipologia de habitação) e a classificação da vulnerabilidade pelas condições dessas variáveis. A dinâmica espacial das bacias fluviais urbanizadas permitiu verificar que o maior número de pontos com registro de inundações ocorreu na bacia do rio Tigre, local com alto grau de vulnerabilidade socioeconômica.

Palavras-chave: Urbanização, Planejamento, SIG, Desastres naturais.

\section{FLOODS AND SOCIOECONOMIC VULNERABILITY IN THE URBAN AREA OF ERECHIM, RS (BRAZIL)}

Abstract: Floods in urban areas has been a serious problem, as they affect a certain amount of population and cause damage, often irreparable to communities and city spaces. This work presents a methodology to assist the identification of areas of hazard of flooding and socioeconomic vulnerability in a study in the city of Erechim, located in the northern portion of Rio Grande do Sul / Brazil that records, according to the municipal civil defense and newspaper reports, significant flooding points. The results were obtained by analyzing the points identified as recurring floods in periods of intense rain and socioeconomic data (income, literacy, demographic density and housing typology) and the classification of vulnerability by the conditions of these variables. The spatial dynamics of urbanized river basins allowed to verify that the greatest number of points with record of floods occurred in the Tigre river basin, a place with high degree of socioeconomic vulnerability.

Keywords: Urbanization, Planning, GIS, Natural disasters.

\footnotetext{
${ }^{1}$ Doutorando em Geografia pela Universidade Federal de Santa Maria (UFSM). Email: andre.ricardofurlan@ gmail.com

${ }^{2}$ Professora Adjunta do Curso de Geografia da Universidade Federal da Fronteira Sul - UFFS/Campus Erechim (RS). Email: jucara.spinelli@uffs.edu.br
} 


\section{INTRODUÇÃO E CONCEPÇÕES TEÓRICAS}

Os desastres naturais são processos que demarcam a exposição de determinadas populações aos riscos perante os fenômenos naturais que atuam no planeta Terra. Nas cidades brasileiras, identifica-se, atualmente, uma conexão intrínseca entre o processo de urbanização e as ocorrências desses desastres. Essa relação ocorre, em grande parte, pelas constantes e intensas modificações nos componentes naturais (solo, hidrografia, uso da terra, ocupação em áreas inadequadas, entre outros).

Nesse contexto, Robaina e Trentin (2013, p.25), também, relatam que "no mundo inteiro, os riscos decorrentes de eventos naturais aumentaram de forma significante nas últimas décadas, tanto os desastres naturais desencadeados por processos internos como aqueles associados aos processos exógenos". Nunes (2013, p.183) considera que o "desastre natural é doravante entendido como um processo contínuo, que traz interrupção ou até mesmo a ruptura das funcionalidades do território, causando perdas que excedem a capacidade do grupo afetado em superar as consequências".

Robaina e Trentin (2013, p.11) mencionam que são "expressivos os registros de acidentes e desastres associados a processos superficiais de dinâmica de encosta e de dinâmica fluvial, acarretando prejuízos e perdas significativas, inclusive de vidas humanas". Logo, são necessários estudos que identifiquem áreas de exposição aos perigos naturais e, também, debatam iniciativas de ordenamento, regulação e planejamento urbano para a utilização dessas áreas.

Nunes (2013) esclarece que os desastres naturais são mais agravados nas cidades, pois elas apresentam a maior densidade demográfica e a concentração de infraestruturas. Além disso, tendem a constituir áreas com pouca estabilidade física dos elementos da natureza, as quais se agravam com a degradação decorrente do uso intenso do solo urbano, da falta de planejamento, com transformações socioespaciais rápidas e intensas. Assim, "os desastres naturais revelam um dos muitos lados da relação complexa entre seres humanos e seu ambiente físico" (NUNES, 2013, p.183).

Em decorrência de um desastre natural, geram-se os perigos naturais urbanos. Nesse aspecto, Robaina e Trentin (2013, p.27) descrevem o "perigo como um evento, processo, ação ou fenômeno que pode causar danos à propriedade, perturbação social e econômica e até perda de vidas". Almeida (2011) argumenta e explicita que o conceito de perigo demanda da probabilidade ou da própria ocorrência de um evento que possa causar prejuízo.

É de conhecimento geral que as inundações se constituem como um dos desastres naturais que comumente se apresentam de maneira expressiva nas cidades brasileiras. Tucci $(2003$, p.45) ressalta que "a inundação urbana é uma ocorrência tão antiga quanto as cidades ou qualquer aglomeramento urbano". Almeida e Carvalho (2010, p.36) salientam, que dos fenômenos denominados como naturais, o que sucede na bacia hidrográfica e possui "estreita relação com a dinâmica fluvial, as inundações são consideradas as maiores causadoras de desastres, com as maiores consequências e grandes parcelas de vítimas e prejuízos, principalmente em extensões territoriais densamente povoadas".

Para Nunes (2015, p.22), as inundações derivam a partir de vários fatores, entre eles estão as "feições atmosféricas, topografia, características das bacias hidrográficas, e uso da terra, aspectos que se alteram em importância ao longo do 
tempo, dado o dinamismo dos elementos físicos e principalmente, da sociedade". As inundações trazem grandes perdas econômicas, e "favorecem a proliferação de vetores transmissores de enfermidades, como dengue, casos de gripe e pneumonia igualmente pode ser ampliados" (NUNES, 2015, p.22).

Tucci $(2003$, p.45) ressalta que os eventos que levam à ocorrência de inundação "podem ocorrer devido ao comportamento natural dos rios ou ampliados pelo efeito de alteração produzida pelo homem na urbanização pela impermeabilização das superfícies e a canalização dos rios". Esse processo evidencia-se a partir do momento em que "as águas dos rios, riachos, galerias pluviais saem do leito de escoamento devido à falta de capacidade de transporte de um destes sistemas e ocupa áreas onde a população utiliza para moradia, transporte (ruas, rodovias e passeios), recreação, comércio, indústria, entre outros" (TUCCl, 2003, p.45).

Nesse sentido, para além dos fatores que levam à ocorrência das inundações, associados aos regimes de forte intensidade de chuvas e aos efeitos da urbanização sobre a rede de drenagem, torna-se importante considerar a situação socioespacial e econômica dos moradores dessas localidades. Dessa forma, entende-se que o conceito de vulnerabilidade socioeconômica-estrutural é necessário para mensurar o potencial de perda da população, a partir de efeitos perigosos ocasionados pelo desastre natural. Entretanto, identificar apenas a periculosidade dos fenômenos não é suficiente para análise do risco, pois é pertinente conhecer e identificar a vulnerabilidade da população exposta ao perigo, para, assim, ter resultados consistentes na avaliação do risco. Isto posto, devem-se verificar as características socioeconômicas da população, para que se possa chegar à noção de vulnerabilidade e, desta forma, compreender a relação do risco empregado à população (CUNHA; RAMOS, 2013).

Para chegar a uma análise da vulnerabilidade se faz necessária "uma abordagem integradora, que procure explicar as complexas interações entre sistemas sociais, naturais e artificiais" (CUTTER, 2009, p.60). Além disso, é preciso levar em consideração a realidade socioeconômica "dos elementos expostos ao evento, sendo diferenciadas dentro de um determinado país, região, estado e cidade, assim como em um assentamento urbano" (ROBAINA; TRENTIN, 2013, p.28). Ademais, a vulnerabilidade e a pobreza trazem à tona condições "sociais que se reforçam mutuamente, ou seja, estão no mesmo lado da moeda, conforme a analogia feita pelos próprios autores ao comparar que uma ameaça ao atingir uma população vulnerável, torna-as mais pobres". (WILLISON; WILLISON, 2003 apud SAITO, 2011, p.11).

No estudo de Goerl, Kobiyama e Pellerin (2012, p.89), é mencionado que "estimar a vulnerabilidade é imprescindível para que se possa realizar a análise e mapeamento de risco". Por meio de indicadores para mensurar a vulnerabilidade, os autores tomaram por base as características socioeconômicas coletadas durante o Censo de 2000, pelo Instituto Brasileiro de Geografia e Estatística (IBGE) e aplicaram à realidade local do município do Rio Negrinho/SC. Tal metodologia também foi utilizada no presente trabalho, sendo melhor explicitada no item sobre os procedimentos metodológicos. A pesquisa dos autores apontou quais os setores censitários (IBGE, 2011) possuem maior risco, os quais devem ser alvo de políticas públicas e medidas mitigadoras na cidade de Rio Negrinho/SC. Além disso, através do índice de vulnerabilidade, foi aprofundada a análise do município em relação às 
características socioeconômicas, determinando as áreas prioritárias para investimentos públicos.

A representação espacial da vulnerabilidade, ou seja, a visualização de sua localização, numa dada porção do espaço, permite que se evidencie, segundo Santos (2015, p.85) "a presença desigual dos grupamentos sociais no território, distribuição esta que segue estreita relação com a disponibilidade de infraestrutura urbana e o valor do solo urbano, refletindo a lógica dos produtores e incorporadores imobiliários". Cutter (2009, p.61) elenca dois princípios para a ciência da vulnerabilidade: no primeiro, afirma que "a vulnerabilidade tem origem no potencial de perda e de impacto negativo que estes sistemas e/ou estruturas têm nas pessoas, ao falhar", no segundo considera que "é requisito do conhecimento geoespacial e da investigação com base nos locais. Todos os desastres são locais e as respostas imediatas também o são". Desta forma, o conceito de vulnerabilidade busca compreender a dimensão dos sistemas sociais. Nesse sentido, a vulnerabilidade socioeconômica-estrutural foi evidenciada a partir do recorte espacial do setor censitário, considerando-se o fato de que cada setor possui uma base de dados oficial e confiável em menor área sobre o domínio nacional.

O presente artigo sintetiza parte de uma pesquisa, a qual teve como base a hipótese de que o desconhecimento ou desatenção dos/aos componentes naturais, aliado à ineficiência no planejamento ambiental e a incapacidade de exercer um ordenamento territorial, tem motivado sérios problemas. Essa situação expõe a população ao perigo de inundação, que, por conseguinte, faz com que as pessoas em situação de vulnerabilidade sofram duramente seus efeitos. O estudo foi realizado na área urbana de Erechim/RS, em bairros que apresentaram registros de inundação entre 1981 e 2017, e em que foram analisados os indicadores da vulnerabilidade socioeconômica (renda, alfabetização, densidade da população residente e domicílio tipo casa) dos setores censitários. O presente trabalho tem como objetivo caracterizar de maneira pontual os locais em que ocorrem processo de inundação, além de categorizar a vulnerabilidade dos setores censitários afetados, utilizando dados secundários do Censo Demográfico de 2010.

\section{ÁREA DE ESTUDO}

A área de estudo escolhida é a cidade de Erechim, que se situa na porção norte do estado do Rio Grande do Sul, região do Alto Uruguai e microrregião geográfica de Erechim (IBGE), composta por 30 municípios. Caracteriza-se, atualmente, como uma cidade polo regional e, segundo o Censo Demográfico 2010 (IBGE), a população total do município era de 96.087 habitantes, sendo $97 \%$ residentes na zona urbana (90.552 habitantes). O mesmo tem como limites: ao norte, os municípios de Aratiba (A) e Três Arroios (B); ao leste, Gaurama (C) e Áurea (D); ao sul, Getúlio Vargas (E), Erebango (F) Quatro Irmãos (G) e ao oeste os municípios de Paulo Bento $(\mathrm{H})$ e Barão de Cotegipe (I) (Figura 1).

O traçado urbano inicial de Erechim (1914) foi proposto por Torres Gonçalves, que projetou "uma malha em grelha sobre a qual implantou quatro vias diagonais que partem da praça central, simbolizando a concentração do poder" (AVER, 2008, p.68). Influenciado por ideias positivistas, de um forte ordenamento, ele preconizou a implantação de tal malha urbana. Contudo, esse traçado tem melhor adequação em áreas de topografia suave e levemente ondulada, sendo que nessa área da sede existiam porções relativamente planas e outras com pendentes moderadas a fortes. 
Assim, já na concepção do traçado do núcleo urbano deveriam ter sido levadas em consideração as condições da topografia do local e da rede de drenagem natural, sendo que muitos pontos da cidade exigiam um tratamento diferenciado. Peretti (2013, p.54) ressalta que a cidade está assentada sobre um relevo de derrames vulcânicos em patamares "e as direções de fraturas facilitam o processo de dissecção. O relevo configurado por morros com topos preferencialmente planos e declives acentuados se deve a presença de vales e interflúvios".

Figura 1. Erechim, RS: localização da área de estudo.

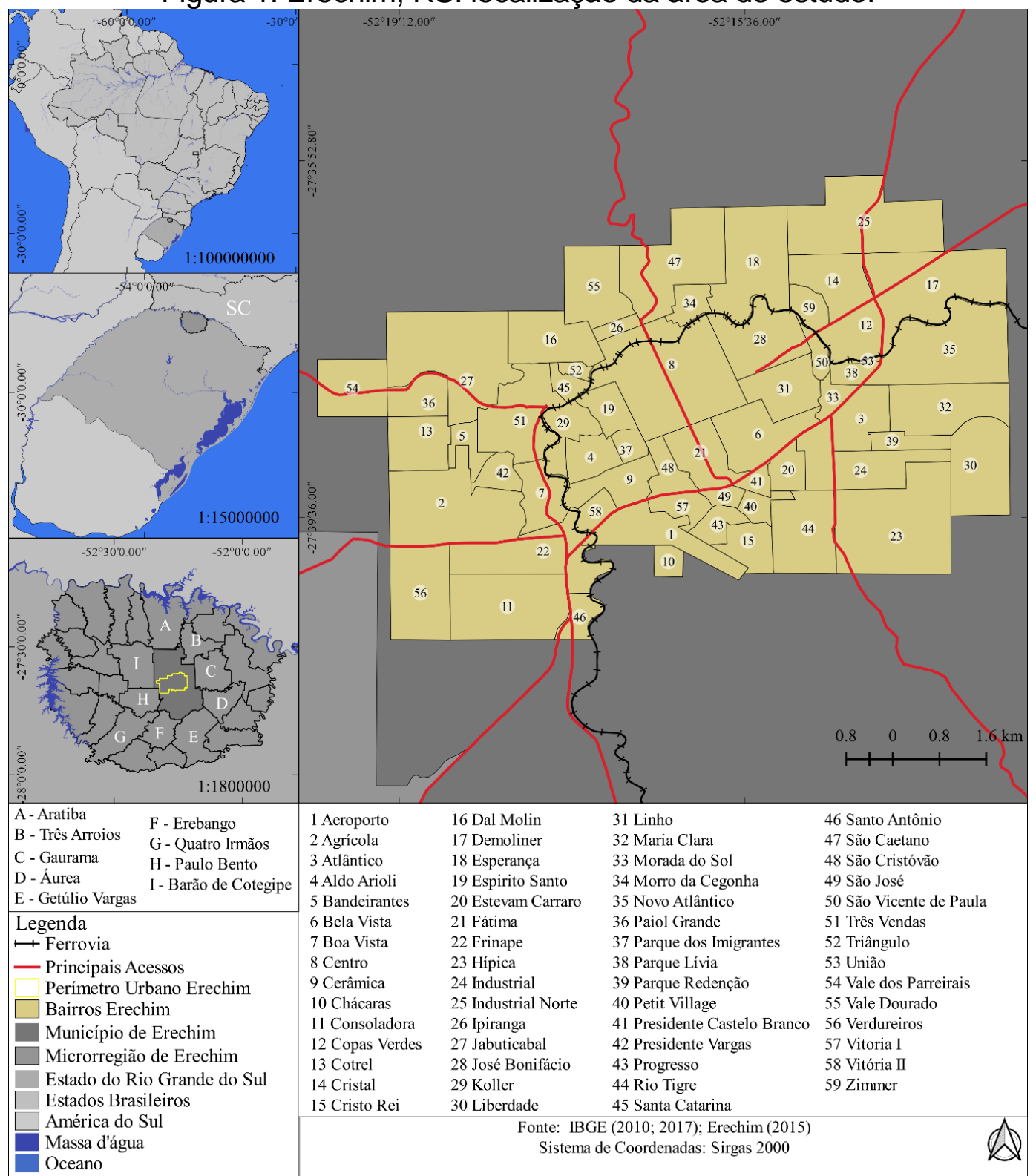

Fonte: Elaborado pelos os autores, 2021

Nos últimos anos, especialmente a partir dos anos 2000, evidencia-se, no Brasil, o aumento da população residindo em áreas urbanas, especialmente em cidades médias e polos regionais, fato que também se revela em Erechim, RS. Nessa cidade polo regional, para dar conta do rápido crescimento populacional urbano, surgiram inúmeras construções em novos loteamentos, inclusive alguns 
realizados a partir de programas habitacionais advindos de políticas públicas. Muitos desses empreendimentos foram efetivados em locais afastados da área central, nas bordas do perímetro urbano e, em alguns casos, em glebas loteadas em áreas que representam perigo para população. Em verificação nos levantamentos de campo, tais áreas com situações de perigo estão em: a) porções com forte declividade ou em encostas ou b) locais rebaixados, com pouca declividade, geralmente próximos aos canais de drenagem fluvial ou em planícies de inundação. Coelho-Neto e Avelar (2007) salientam que são nessas áreas em que mais ocorrem, de maneira aguda, os movimentos de massa e os processos de inundação. Sendo assim, a cidade foi se expandindo de forma a ampliar, significativamente, a mancha urbana, por meio da autorização de loteamentos de novos empreendimentos imobiliários, muitos deles, que podem gerar perigo à população por sua localização em porções passíveis de problemas decorrentes da drenagem urbana. Por outro lado, nas áreas centrais, o adensamento populacional passou a se constituir, evidenciando o processo de verticalização que ocorre pela substituição de terrenos, os quais possuíam casas como moradia e, também, nos antigos vazios urbanos. Esse adensamento altera a dinâmica ambiental, desencadeando processos de impermeabilização do solo, de canalizações, retificações de canais de drenagem e de ocupações de áreas de encosta (FURLAN, 2016).

\section{METODOLOGIA, MATERIAIS E PROCEDIMENTOS}

A orientação metodológica da pesquisa perseguiu três procedimentos básicos: revisitar as matrizes teóricas sobre o tema; levantar, compilar e analisar os dados dos pontos de inundações e, por fim, sistematizar e analisar os dados referentes à vulnerabilidade socioeconômica e espacial.

O suporte teórico para a pesquisa constituiu a revisão bibliográfica, essencial para compreender as definições de desastres naturais, assim como, os conceitos de perigo e seus processos e a vulnerabilidade. A fim de verificar a aplicação desses conceitos, foi definida como área de estudo a cidade de Erechim, localizada na porção norte do estado do Rio Grande do Sul. Tal recorte espacial foi selecionado por dois fatores: a) o volume de ocorrências de inundações registradas pelos jornais locais e Defesa Civil, sendo significativas nessa porção do estado e b) o forte crescimento da cidade nos últimos anos, com processo de adensamento de áreas centrais e de expansão da mancha urbana. Para corroborar com a compreensão da expansão da malha urbana do município de Erechim, foram utilizadas duas imagens de livre acesso, do software Google Earth Pro, de 30 de dezembro de 1984 e de 28 de outubro de 2016, sendo sobrepostos sobre a imagem a base cartográfica, a qual abrange todos os bairros (2015) e os setores censitários do IBGE (2011), que estão sob evidência de perigo de inundações.

Por conseguinte, os dados referentes aos problemas de inundações foram adquiridos em Reckziegel (2007) e Peretti (2013) e em pesquisas realizadas junto ao Acervo Histórico municipal, localizados em jornais locais e em arquivos da Defesa Civil Municipal. Ressalta-se, então, que foram identificados e analisados, na área de estudo, os locais em que tais eventos ocorreram de forma mais intensa. Contudo, não foram utilizados critérios de uma periodicidade regular dos eventos, devido ao volume de ocorrências não linear temporalmente. De todo modo, o recorte temporal dos eventos de inundações, levantado junto à Defesa Civil, abrange o período de 2014 a 2017, por conter informações relativamente de fácil acesso. Ademais, para a 
avaliação do perigo não se utilizaram classes específicas, tendo em vista a indisponibilidade de dados de precipitação e de altimetria em detalhe das áreas atingidas até o momento.

Para a definição e a avaliação da vulnerabilidade procuraram-se referências em estudos já realizados, tais como: a) o trabalho de Goerl, Kobiyama e Pellerin (2012), no qual utilizam o número de moradores no setor, média de moradores por domicílio, densidade demográfica, \% da população acima de 65 anos, \% da população abaixo de 12 anos, \% de pessoas analfabetas acima de 12 anos, \% de responsáveis sem rendimento; b) Santos (2015), o qual utiliza as variáveis educação, renda, saneamento e situação social; c) Gonzales e Costa (2016), os quais utilizam, em seu trabalho, as variáveis renda, alfabetização, percentual de crianças e percentual de idosos e d) Mendonça et al. (2016), os quais utilizaram as variáveis alfabetização e renda, lixo no logradouro, ocupação irregular, rede de esgoto ou fossa séptica, coleta de lixo e abastecimento de água.

Dentre as variáveis apresentadas pelos diversos autores, considerou-se, neste trabalho, as seguintes variáveis para definir a vulnerabilidade socioeconômicaestrutural: a renda, a alfabetização, a densidade demográfica e a tipologia das residências (casa). As variáveis, coleta de lixo, abastecimento de água e rede de esgoto ou fossa séptica aparecem de maneira homogênea na área urbana. Dessa feita, ao realizar o teste das diversas variáveis disponibilizadas pelo o Censo Demográfico 2010 (IBGE, 2011), optou-se por analisar os domicílios tipo casa. É válido ressaltar que as quatro variáveis estão expostas no Quadro 1 e detalhadas a seguir. Considerou-se, para a definição dessa variável (tipologia de casas), o fato de estar mais relacionado ao padrão de construções das moradias urbanas dos setores censitários, os quais apresentaram maiores indicadores de perigo de inundação e identificação de situações de maior vulnerabilidade estrutural da moradia. Em vista disso, foi definido o padrão das construções - uma vez que as construções precárias são mais impactadas do que as com estrutura mais resistente, a exemplo de estruturas prediais, relacionado à ocorrência de um evento de inundação.

Segundo pesquisas, o IBGE (2011, p.17) define domicílio como sendo "o local estruturalmente separado e independente que se destina a servir de habitação a uma ou mais pessoas, ou que esteja sendo utilizado como tal". Os dados e bases referentes ao setor censitário e aos domicílios foram adquiridos na página do IBGE. Além dos setores considerados urbanos, acrescentaram-se mais três setores (130, $140,151)$, para os quais, segundo os trabalhos de campo realizados, verificou-se que não possuem aspectos de espaços rurais, mas sim usos urbanos. Já para análise da renda, foram analisados 138 setores; para a alfabetização, 137 setores; para a densidade populacional, 138 setores e para os domicílios tipo casa, 135 setores. 
Quadro 1. Variáveis socioeconômicas-estruturais.

\begin{tabular}{|c|c|}
\hline \multicolumn{2}{|c|}{ RENDA } \\
\hline Descrição da variável/conceito & Fonte de consulta/cálculo \\
\hline $\begin{array}{l}\text { Domicílio particular permanente } \\
\text { Domicílio construído para servir, exclusivamente, à } \\
\text { habitação e, na data de referência, tinha a finalidade de } \\
\text { servir de moradia a uma ou mais pessoas (IBGE, 2011, } \\
\text { p.18). }\end{array}$ & $\begin{array}{l}\text { 6.1 Arquivo Básico (planilha Básico_UF.xls ou } \\
\text { Básico_UF.csv) } \\
\text { V005 Valor do rendimento nominal médio mensal das } \\
\text { pessoas responsáveis por domicílios particulares } \\
\text { permanentes (com e sem rendimento). }\end{array}$ \\
\hline \multicolumn{2}{|c|}{ ALFABETIZAÇÃO } \\
\hline $\begin{array}{l}\text { Alfabetização } \\
\text { Alfabetizada é a pessoa capaz de ler e escrever um bilhete } \\
\text { simples no idioma que conhecesse. Analfabeta é a pessoa } \\
\text { que aprendeu a ler e escrever, mas que esqueceu devido a } \\
\text { ter passado por um processo de alfabetização que não se } \\
\text { consolidou e a que apenas assinava o próprio nome } \\
\text { (IBGE, 2011, p.26). }\end{array}$ & $\begin{array}{l}\text { 6.5 Arquivo Responsável pelo domicílio, total e homens } \\
\text { (planilhaResponsável02_UF.xls } \\
\text { Responsavel02_UF.csv) } \\
\text { V001 Pessoas Responsáveis; V093 Pessoas Responsáveis } \\
\text { alfabentizados. }\end{array}$ \\
\hline \multicolumn{2}{|c|}{ DENSIDADE POPULACIONAL } \\
\hline $\begin{array}{l}\text { Densidade demográfica } \\
\text { Medida da distribuição espacial da população que permite } \\
\text { o estudo da concentração ou dispersão dessa população } \\
\text { no espaço geográfico considerado. Calculada pelo número } \\
\text { de habitantes por unidade de superfície, expressa pela } \\
\text { expressão hab } / \mathrm{km}^{2} \text { (IBGE, 2009, Séries Históricas). }\end{array}$ & $\begin{array}{l}\text { 6.1 Arquivo Básico (planilha Básico_UF.xls ou } \\
\text { Básico_UF.csv) } \\
\text { V002 Moradores em domicílios particulares permanentes ou } \\
\text { população residente em domicílios particulares permanentes. } \\
\text { Esse dado foi extraído do cálculo da divisão do número de } \\
\text { moradores em domicílios particulares permanentes ou } \\
\text { população residente em domicílios particulares permanentes } \\
\text { (V002) com a área do setor censitário. Para o cálculo dessa } \\
\text { densidade foi utilizada a fórmula: V002/área do setor }= \\
\text { habitantes } / \mathrm{km}^{2} \text {. }\end{array}$ \\
\hline \multicolumn{2}{|c|}{ DOMICÍLIOS TIPO CASA } \\
\hline $\begin{array}{l}\text { Tipo de domicílio (Casa) } \\
\text { A tipologia casa é uma edificação de um ou mais } \\
\text { pavimentos, desde que ocupada integralmente por um } \\
\text { único domicílio, com acesso direto a um logradouro } \\
\text { (arruamento, vila, avenida, caminho etc.), legalizado ou } \\
\text { não, independentemente do material utilizado em sua } \\
\text { construção (IBGE, 2011, p.20). }\end{array}$ & $\begin{array}{l}\text { 6.2 Arquivo Domicílio, características gerais (planilha } \\
\text { Domicilio01_UF.xls ou Domicilio01_UF.csv) } \\
\text { V002 Domicílios particulares permanentes } \\
\text { V003 Domicílios particulares permanentes do tipo casa. }\end{array}$ \\
\hline
\end{tabular}

Fonte: adaptado de IBGE (2011)

Dessa forma, com a posse dos dados, cada variável transposta para tabela foi dividida a partir do Quantil (o qual divide o intervalo de frequência de uma amostra em partes iguais), sendo utilizadas apenas três classes para cada variável, assim expressando valores de que variam entre 1, 2 e 3 (Baixa, Média e Alta) como se verifica no quadro seguinte (Quadro 2).

Quadro 2. Classificação das variáveis de vulnerabilidade

\begin{tabular}{|c|c|c|c|}
\hline \multicolumn{4}{|c|}{ Variáveis socioeconômicas-estruturais } \\
\hline Renda & Alfabetização & $\begin{array}{c}\text { Densidade } \\
\text { populacional }\end{array}$ & $\begin{array}{c}\text { Domicílios tipo } \\
\text { casa }\end{array}$ \\
\hline Alta (1) & Alta (1) & Baixa (1) & Baixa (1) \\
\hline Média (2) & Média (2) & Média (2) & Média (2) \\
\hline Baixa (3) & Baixa (3) & Alta (3) & Alta (3) \\
\hline
\end{tabular}

Fonte: Elaborado pelos autores, 2021

Compreende-se, então, que a vulnerabilidade Socioeconômica-estrutural encontra-se expressa pela soma dos valores atribuídos a cada variável utilizada dentro de um setor censitário. Por conseguinte, a somatória de 4 a 6 representa vulnerabilidade Socioeconômica-estrutural Baixa. A Média encontra-se entre os valores 7 a 9 e a Alta varia entre 10 a 12 .

Para avaliar a vulnerabilidade foram utilizados os dados de todos os setores considerados urbanos, para não ocorrer discrepâncias, totalizando 135. A análise da 
vulnerabilidade trata-se de uma somatória do valor atribuído pelas classes da vulnerabilidade dos setores censitários em que acontecem as inundações.

No respectivo trabalho ocorreram algumas dificuldades nas sistematizações dos resultados, devido às escalas de análise adotadas. Além disso, verificaram-se descompassos entre a área do bairro e o setor censitário, que em muitos casos não correspondiam a mesma área, pois um setor censitário pode sobrepor mais de um bairro ou dividir um bairro. Mesmo assim, a base vetorial do setor censitário foi adquirida diretamente no site do IBGE, sendo adaptada às áreas dos bairros.

\section{RESULTADOS E DISCUSSÕES}

A área urbana de Erechim apresenta problemas de ordem estrutural relacionada às inundações, tanto em função da urbanização em áreas não adequadas ou que não tiveram mitigação por obras de engenharia, quanto pelo adensamento sem a preservação dos canais naturais. Assim sendo, a partir desses elementos, a urbanização tornou-se um intensificador na recorrência dos casos de inundação em Erechim, conferindo à população a exposição ao perigo relacionado aos processos associados à dinâmica fluvial.

Dessa forma, a expansão urbana de Erechim, apresentando um comparativo temporal de 32 anos (1985 e 2017) pode ser observada nas imagens que seguem (Figuras 2). Sobre as imagens é possível identificar polígonos contendo todos bairros do perímetro urbano e setores censitários com ocorrência de inundação. Os principais acessos e a ferrovia que perpassa toda área urbana estão representados em forma de linhas.

Figura 2: Imagens de satélite e setores censitários de Erechim/RS:

A) Ano de 1985 e B) Ano de 2017

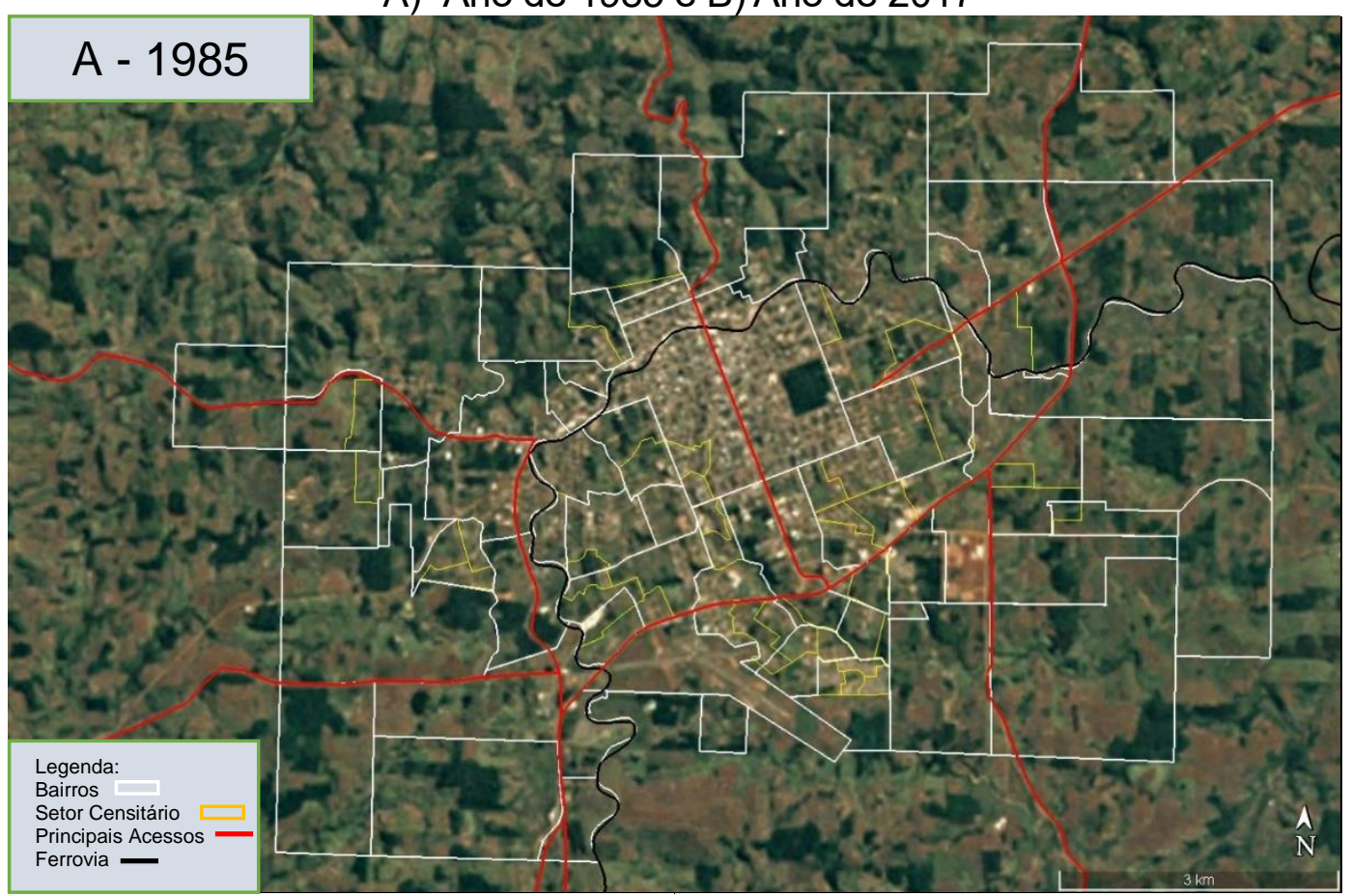




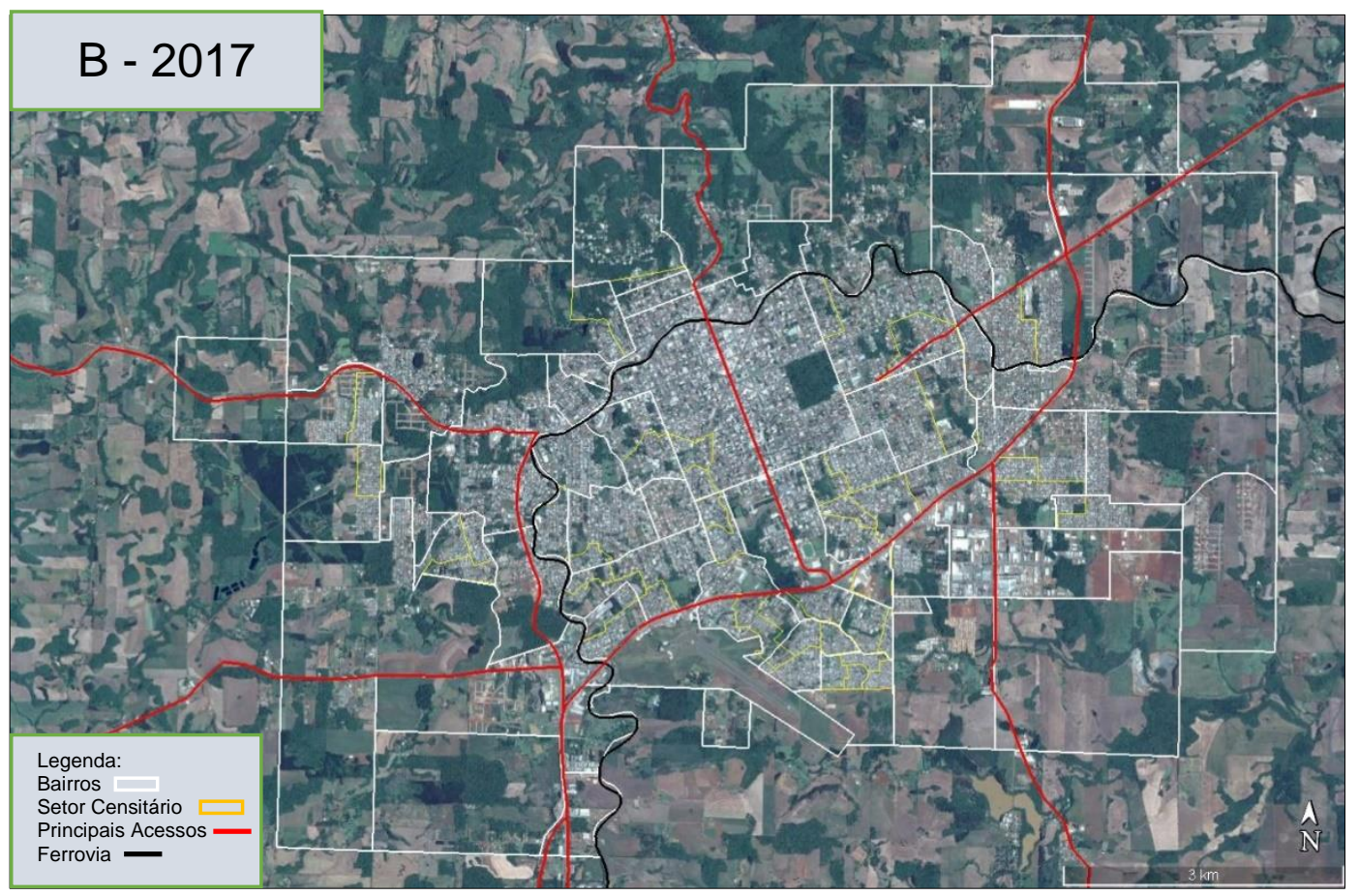

Fonte: Google Earth Pro e IBGE, 2010. Organizado pelos autores, 2021

Nessas imagens, pode-se identificar as áreas ocupadas, evidenciando porções de maior adensamento e outras que mostram o espalhamento da cidade, aumentando a mancha urbana. Visualiza-se que no ano de 1985 (Figura 2A), o bairro Centro e Ipiranga encontram-se em estágio consolidado de ocupação urbana. Os bairros São Cristóvão, Fátima, Bela Vista em estágio avançado de ocupação. E os bairros Cristo Rei e Industrial em estágio inicial de estruturação. Para o ano de 2017 (Figura 2B), verifica-se grande parte dos bairros com estágio de ocupação urbana consolidado, outros bairros ainda se encontram em estágio inicial de ocupação. Alguns desses bairros criados com a delimitação do perímetro urbano no ano de 2015 como por exemplo os bairros Hípica, Liberdade, Novo Atlântico, Demoliner, Industrial Norte, Esperança, Agrícola, Verdureiros e Consoladora.

As imagens da Figura 2 demonstram a expansão da cidade e novos loteamentos e usos, a exemplo do que se pode visualizar na porção direção sul, leste e oeste da cidade. $\mathrm{Na}$ imagem de 1985, percebe-se que a cidade estava limitada pelos perímetros da rodovia em sua porção S-SE; já na imagem de 2017 a expansão urbana ultrapassou essa via que, de certa forma, entrecorta a cidade. Essas novas expansões avançaram tanto em áreas de nascentes, em encostas e porções rebaixadas, junto às planícies de inundação próximas aos canais fluviais. A partir da consolidação urbana foram se estabelecendo usos e ocupações urbanas de novas glebas que apresentam perigo de inundação. O detalhamento da situação decorrente desse processo de ocupação recente está apresentado no item que segue.

\section{PERIGO ASSOCIADO ÀS INUNDAÇÕES}

Nos espaços urbanizados, os processos de inundações para Almeida e Carvalho (2010, p.36) "estão entre as ameaças naturais que mais causam danos humanos e materiais". Esses fenômenos ocorrem devido à ocupação incoerente 
para múltiplos fins, desse modo, não respeitando a dinâmica "natural" da bacia fluvial. No entanto, a "inocência" das pessoas que residem nas margens dos rios, geralmente com situação socioeconômica precária, vulneráveis pela sua condição de baixa escolaridade e sem outra opção para moradia, torna-se mais um agravante do risco. Vivem em situação cujo tamanho do perigo de inundações passa despercebido ou desconsiderado.

A área urbana de Erechim está assentada sobre quatro bacias hidrográficas, todas impactadas pela urbanização, as quais são: a do rio Dourado, do rio Henrique, do rio Suzana e do rio Tigre. A Figura 3 apresenta a distribuição dos bairros de Erechim que possuem registros de eventos entre os anos de 1981 e 2017. Após a nova delimitação do perímetro urbano, em 2015, apresenta 59 bairros, e desses, 22 bairros tiveram registro de problemas ligados às questões hidrológicas. A bacia hidrográfica do rio Tigre possui maior percentual de área urbanizada e concentra a maioria dos bairros que sofrem com inundação, embora, a partir de 2012, esse fenômeno pode ser identificado em outras bacias hidrográficas do perímetro urbano.

A bacia fluvial do rio Dourado, direção norte e noroeste (Figura 3), possui registro de inundação no bairro Ipiranga, onde o processo se pronuncia na rua José Pigozzo. Esse processo decorre de aterros realizados para construção da rua. Essa área recebe água fluvial, pluvial e esgoto cloacal produzido em parte do bairro. Segundo relato de moradores, após forte chuva toda canalização foi arrancada e, posteriormente, assoreada com despejo de sedimentos. Esse fato fez com que ocasionasse o processo que consiste na invasão das águas em uma residência próxima e inviabilização do acesso de outros moradores para suas casas. Além da questão referente às inundações, um morador relata o forte odor de esgoto após a obstrução da canalização, o qual passou a escorrer a céu aberto.

Figura 3. Erechim, RS: Bairros em situação de perigo de inundações

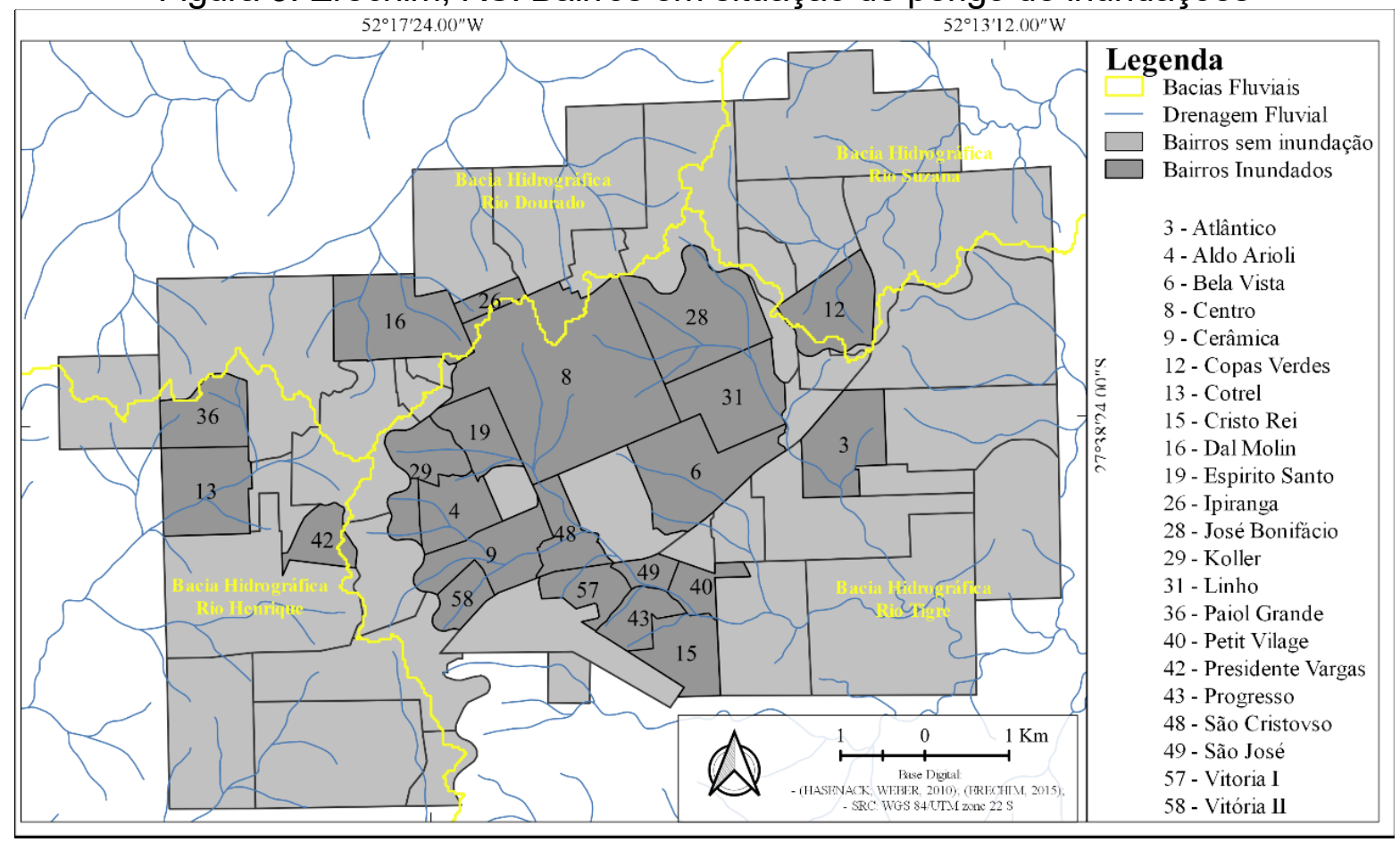

Fonte: Elaborado pelos autores, 2021 
No bairro Dal Molin, os casos são registrados no cruzamento das ruas Antônio Dal Molin com Bento Gonçalves. A inundação acontece devido à ineficiência das drenagens submersas, uma vez que nesse ponto encontra-se uma das nascentes do rio Dourado (Figura 3). Nesse episódio, podem ser apontados três elementos atuando no processo: a) expansão urbana (impermeabilização da terra); b) demanda para o escoamento das águas pluviais, fluviais e servidas e, c) ineficiência hidráulica na construção das drenagens submersas. A partir desses elementos, o canal não suporta toda a vazão e transborda pela boca de lobo, atingindo diversas casas.

$\mathrm{Na}$ bacia fluvial do rio Suzana, direção nordeste (Figura 3), tem-se ocorrências mais frequentes no bairro Copas Verdes, em que o ponto de inundação está localizado entre as ruas Sidney Guerra, Fortaleza, Dos Ipês e Fausto Demoliner. Em todos os casos, identifica-se que esse problema é causado pelas intervenções no canal fluvial por meio de canalização de parte do manancial para a construção do loteamento denominado Copas Verdes. O fenômeno ocorre devido à baixa vazão das tubulações. A água que não escoa pela drenagem sobe até a superfície e ocupa as áreas planas, como pode ser observado na Figura 4a.

Figura 4. Inundações nos bairros: a) Copas Verdes; b) Cotrel.
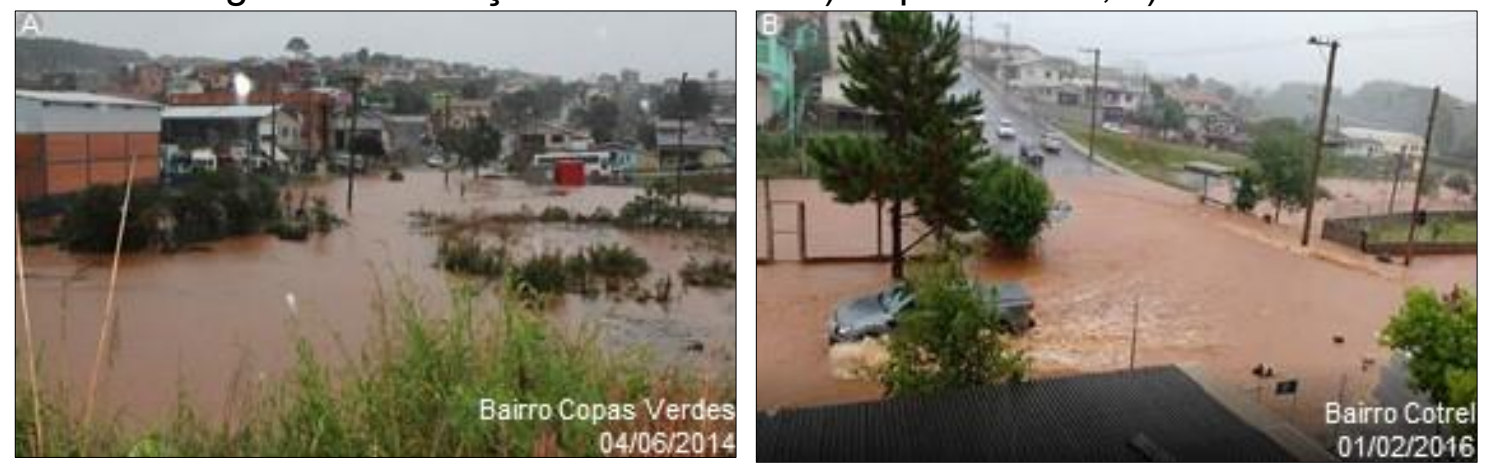

Fonte: Au Online. (2014; 2016). Organizado pelos autores, 2021

Na bacia fluvial do rio Henrique, direção oeste e sudoeste (Figura 3), tem-se registros de inundações no bairro Presidente Vargas, em dois pontos da rua Belo Cardoso, os quais fazem com que as drenagens não suportem a vazão das águas fluviais de canais de $1^{\mathrm{a}}$ ordem. Esse fator ocorre pela demanda para desaguar as águas pluviais em momento de precipitação e, também, pela descarga de esgoto sem a devida rede de saneamento.

No bairro Paiol Grande, as inundações decorrem em dois pontos: a) no cruzamento das ruas Karol Wojtyla e Anselmo Parmegiani, no local ocorre o encontro das drenagens submersas, dessa forma, concentrando grande volume de água cuja tubulação não suporta sua vazão; b) na rua Anselmo Parmegiani é onde as águas das drenagens submersas encontram-se barradas por um canal fluvial aberto, que possui fluxo maior. Esses problemas hidrológicos ocorrem devido à construção de um loteamento sobre áreas de nascentes. Em períodos de grande precipitação o solo e as drenagens submersas não suportam absorver todo o volume de água, assim, a água invade as residências e ruas desse bairro. $\mathrm{O}$ bairro Cotrel, considerado um bairro novo em comparação aos bairros próximos, como o Ipiranga e o Centro, apresenta diversos problemas de cunho hidrológico, registrados nas ruas Daniel Durli, Angelina Pagliosa Lôra, Balthazar Gáspar Sponchiado e Mauro Antônio Pagliosa. Nessa área, também se efetivou a construção de um 
loteamento, sobre um canal fluvial. A partir da impermeabilização de áreas, a montante a canalização tornou-se insuficiente, por conseguinte, as tubulações não dão conta de escoar toda água, tornando-se um problema para a população, como pode-se observar na Figura $4 \mathrm{~b}$. A água invade as casas e as ruas, dado que o canal nessa área passa a ser de $2^{\mathrm{a}}$ ordem.

$\mathrm{Na}$ bacia fluvial do rio Tigre (Figura 3), por estar com a maior porção de área urbana sobre sua área, tem-se inundações em diversos pontos. No bairro Centro, os casos de maior recorrência são nas ruas Pedro Pinto de Souza e Avenida Farrapos. A ocorrência desses episódios torna-se possível devido à insuficiência na rede de drenagem, a qual não suporta a capacidade de escoamento atual, uma vez que essa área já se encontra estruturada há vários anos e as tubulações e canalizações realizadas não suportam toda densidade de fluidos, os quais são introduzidos quando ocorre grande precipitação. No bairro Espírito Santo, verificaram-se registros na rua Eugênio Montemezzo, nessa área tem-se a insuficiência na rede de drenagem submersas. Próximo a esse local o rio torna-se de $2^{\mathrm{a}}$ ordem e em dias de muita vazão emerge pelas bocas de lobo, causando um fluxo contrário, ao invés de absorver toda água da chuva, ela impulsiona o volume da água do canal fluvial para superfície, obtendo, assim, um refluxo da água fluvial.

O bairro São Cristóvão encontra-se entrecortado, em grande parte, pelo rio Tigre, abrangendo boa porção em seu vale encaixado. No decorrer das décadas, esse canal veio a ser canalizado e submerso, porém, quando ocorre grande precipitação, suas águas retornam para a superfície, alagando diversos terrenos e casas, as quais se encontram sobre as galerias ou mesmo nas imediações do antigo canal. Em outra área da bacia ocorrem casos de inundação nos bairros Koller, Aldo Arioli, Cerâmica e Vitória II, onde os canais que percorrem esses bairros desembocam abaixo dos pontos de inundação do bairro São Cristóvão. No bairro Koller, ocorrem inundações na rua Nelina Ann Spencer, devido à passagem de um canal de $1^{a}$ ordem, próximo a essa rua. A drenagem submersa, construída para escoar essa água, atualmente, não suporta o escoamento das águas, fluviais, pluviais e cloacais.

No bairro Aldo Arioli, tem-se a ocorrência de inundações nas ruas Francisco Cechet, Dr. Nery Reichmann, e no cruzamento da rua Dr. Nery Reichman com David Pinto de Souza. Todos os casos são restritamente ocasionados pela interferência antrópica nos sistemas de drenagem natural da bacia hidrográfica. Na rua Francisco Cechet, percorre uma tubulação de um canal de $1^{\text {a }}$ ordem, na rua Dr. Nery Reichmann esse canal torna-se de $2^{a}$ ordem. Na esquina das ruas Dr. Nery Reichmann com David Pinto de Souza foram realizadas intervenções, desviando o canal. No bairro Cerâmica ocorrem processos hidrológicos em uma rua sem saída e sem nome (rua acima da Dr. Nery Reichman); nesse local encontra-se um canal de $1^{\text {a }}$ ordem, também ocorrem alagamentos na rua Antônio Biolo.

Entre os bairros Cerâmica e Vitória II acontecem inundações na rua Basílio Anzanello, onde esse canal torna-se de $2^{a}$ ordem; na Figura $5 a$ pode-se identificar 0 volume e a concentração de água nesse local. Deve-se ressaltar, que esses processos acontecem devido a canalização mal dimensionada e alterações no canal fluvial. Em continuidade do rio Tigre, existe outro aglomerado de bairros sobre perigo de inundação, a nordeste do canal (Figura 3), têm-se os bairros São José e Pettit Vilage. Esses bairros possuem como divisão o canal fluvial principal. Quando sucedem precipitações elevadas, o nível do canal se eleva ocasionando seu transbordamento e, consequentemente, causando diversos problemas nessa área. 
Na direção sudoeste do canal estão localizados os bairros Vitória I, Progresso e Cristo Rei. O processo de inundação evidencia-se no Vitória I, e construiu-se devido à presença de canalizações insuficientes em um canal de $1^{a}$ ordem, que se localiza na rua São Jorge. Na rua Demétrio Arpini, esse processo ocorre em um afluente de $1^{\mathrm{a}}$ ordem, do mesmo canal a jusante do ponto da rua São Jorge.

Identificaram-se processos de inundação na rua Estevam Gavenda, entre os bairros Cristo Rei e Progresso, o processo nessa área ocorre devido à drenagem insuficiente. Além desse ponto, esses dois bairros fazem limite com o canal principal do rio Tigre e acaba inundando quando ocorre o extravasamento do canal.

Também no bairro Cristo Rei, transcorrem alguns processos em um canal de $1^{\text {a }}$ ordem, afluente do rio Tigre, que foi canalizado e que já não oferece suporte ao escoamento das águas pluviais e fluviais. Dessa maneira, acabam ocasionando, seguidamente, problemas de inundação. Esse processo ocorre nas ruas: Santa Lúcia, São Vítor, Santa Marta e Santa Bárbara. Assim sendo, identifica-se, nesse bairro, que os processos de inundações derivam tanto de problemas de drenagem submersa insuficiente, que estão ligados a canalização de afluentes de $1^{a}$ ordem, quanto a partir do extravasamento do canal fluvial principal, que é de $3^{\mathrm{a}}$ ordem nesse local (Figura 5b).

Figura 5. Inundações nos bairros: a) rua Basílio Anzanello (Cerâmica); b) Cristo Rei.

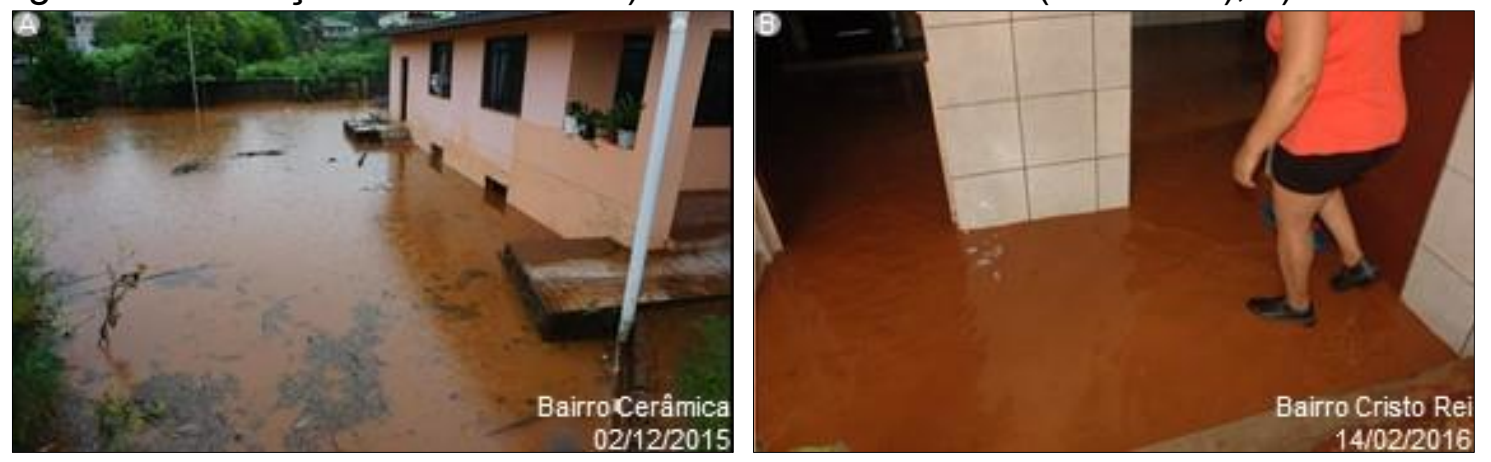

Fonte: Au Online. (2015; 2016). Organizado pelos os autores, 2021

No bairro Bela Vista, os problemas hidrológicos ocorrem diretamente na rua Sergipe, outros dois pontos estão localizados nas ruas Irmãs Franciscanas e Santo Dallazem com Segundo Assoni. A ocorrência desses eventos, vêm em decorrência de drenagem insuficiente. Nesse local, estava contido um canal fluvial que foi canalizado, tem-se que os dois primeiros pontos são canais de $1^{\text {a }}$ ordem, já no último, o canal torna-se de $2^{\mathrm{a}}$ ordem. Logo, a partir de forte precipitação as drenagens construídas não suportam a vazão, assim acaba inundando toda área.

No bairro José Bonifácio, o primeiro ponto a montante ocorre na esquina entre as ruas Amintas Maciel com Quintino Bocaiuva e trata-se de uma canalização insuficiente, pois com o aumento constante na construção de prédios nessa área, tem-se o aumento da vazão nas tubulações e acaba não dando conta de todo o escoamento da água. Também, sucedem inundações em dois pontos na rua Catarina Basso e entre as ruas Sidney Guerra e Pernambuco. Ao observar a Figura $6 a$, abaixo, observa-se o nível de água dentro do imóvel. Identifica-se, que o processo ocorre em área com relevo plano, destarte a água tem facilidade em se acumular. Outra questão pontual, é que essa área fica próxima a um meandro, com volume alto de chuvas a água ultrapassa o canal do rio e atinge diversas residências. Já na rua Catarina Basso o problema ocorre devido à drenagem 
ineficiente, que com o aumento da vazão as águas sobem pelas bocas de lobo e invadem a rua e as casas existentes nesse local.

No bairro Linho, os processos ocorrem em três pontos, o primeiro na rua Pernambuco (Figura 6b), em seguida na rua Zero Hora e, por fim, na Sergipe. No primeiro caso, têm-se duas ocorrências de extravasamento do canal principal e a insuficiência na drenagem de um curso afluente, que se encontra canalizado. Os dois últimos pontos ocorrem devido à proximidade do leito principal, possuindo hierarquia de $2^{a}$ ordem. Nesse local, o canal encontra-se aberto, em dias de grande precipitação extravasa sua cota média e invade as casas, tendo em vista que as casas foram construídas próximas ao rio, como se observa na Figura 7a.

Figura 6. Inundações nos bairros: a) Rua Catarina Basso (José Bonifácio); b) Rua Pernambuco (Linho).

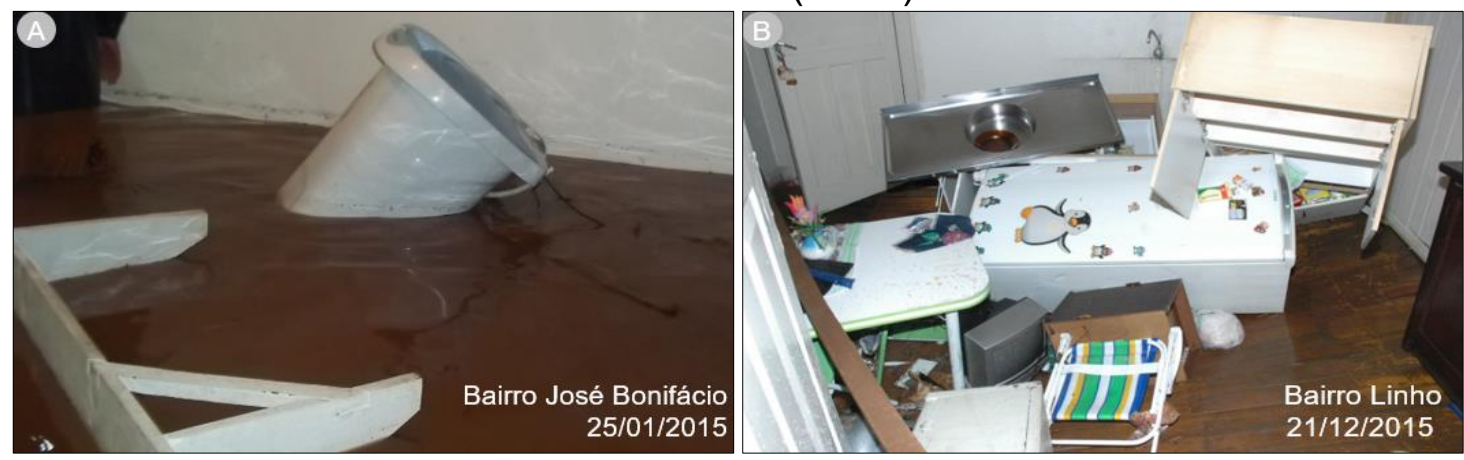

Fonte: Au Online. (2015). Organizado pelos autores, 2021

No bairro Atlântico, as ocorrências dos processos acontecem nas ruas Alberto Peretti e Doutor João Caruso. Também possui registro de mais três casos nas ruas Alvar Isidro Coffy, João Carlos Pereira Monteiro com Cesarino Lopes, e em uma rua sem fim. Além de que se apresentam processos de inundação na rua Miguel Moisyn. Todas essas ocorrências estão ligadas exclusivamente ao canal principal deste curso d'água, o qual é de $3^{a}$ ordem. Igualmente, acontecem afluentes de $1^{a}$ e $2^{a}$ ordem que estão canalizados, na rua Dilgai Parenti e Fulgêncio Miguel Coffy. Já na rua Giácomo Luis Berticelli, as ocorrências nesse setor estão relacionadas a um canal de $1^{\mathrm{a}}$ e $2^{\mathrm{a}}$ ordem. Esse canal foi drenado e canalizado para construção do bairro, e em período de fortes chuvas ele toma seu leito normal, causando diversos problemas nas residências próximas, pode-se observar na Figura $7 \mathrm{~b}$ a grande quantidade de água acumulada, esse ponto é localizado a montante do bairro, essa vazão é exclusivamente de um canal de $1^{\mathrm{a}}$ ordem.

Dessa forma, no presente estudo, o perigo ocorre devido às interferências antrópicas nos canais fluviais, isso em decorrência de dois fatores principais, o primeiro, e mais antigo, consiste no uso dos canais que foram canalizados para descarte do esgoto, produzido a partir da constituição das primeiras residências, ainda na Avenida Mauricio Cardoso, onde as principais nascentes do rio Tigre estão alocadas, essa política tornou-se predominante até os dias atuais. O segundo, constitui-se baseado no valor da terra urbana, em que a partir da canalização de canais de ordens menores, assim, facilitando a construção de loteamentos e a venda de terrenos sobre esses canais. 
Figura 7. Inundações nos bairros: a) Rua Sergipe (Linho); b) Rua Giácomo Luis Berticelli (Atlântico).

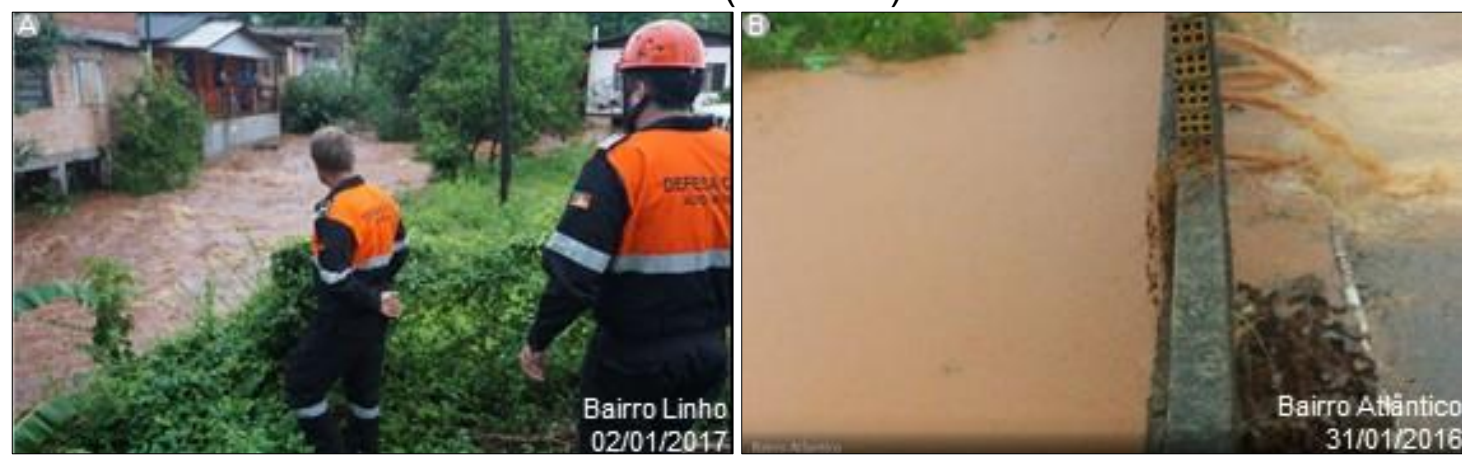

Fonte: Au Online. (2016; 2017). Organizado pelos autores, 2021

Destaca-se, também, que não se observam políticas públicas para manejo e fiscalização tanto nos loteamentos, quanto nos usos terra, que estão ligados fortemente ao ordenamento territorial e ao planejamento ambiental das bacias hidrográficas. Ao observar o resultado, identifica-se que são poucos pontos de inundação em que a população está nas margens dos canais fluviais, em grande parte dos casos vislumbra-se que locais impróprios para locação de residências foram vendidos por terceiros.

Por fim, em relação às bacias fluviais, verifica-se que toda interferência realizada no substrato natural do seu alto curso impacta de forma negativa no seu médio e baixo curso. Trazendo como exemplo a construção de um loteamento a montante de uma bacia hidrográfica, toda essa interferência nos elementos naturais, irá acarretar na maior vazão das águas pluviais para os outros segmentos do canal ou de outros canais fluviais adjacentes. Assim, aumenta-se a proporção da água concentrada nesse canal, podendo ocasionar perigo para a população que vive a jusante.

\section{ANÁLISE DA VULNERABILIDADE POR SETOR CENSITÁRIO}

A vulnerabilidade se refere a algumas características que expressam a existência de populações mais suscetíveis a habitar áreas de eminente risco de inundação, dada pela sua situação socioeconômica. A primeira característica tratase do poder aquisitivo (analisado em geral pelo indicador de renda familiar). Esse quesito influencia fortemente, em um primeiro aspecto, pela condição de localização da moradia. Não raro, locais inadequados à urbanização, como encostas íngremes e fundos de vale, acabam sendo ocupados como alterativa de moradia e/ou pelo seu menor preço. Um segundo aspecto se refere à capacidade de restabelecimento da moradia no mesmo local após a ocorrência de um determinado perigo. Se a população possui poder aquisitivo para comprar os materiais necessários para reconstruir suas casas, vai ser menos vulnerável que um grupo sem nenhuma condição para realizar a reconstrução. Por conseguinte, a renda é fator predominante para evidenciar as desigualdades. Logo, identifica-se que "a vulnerabilidade é maior nos assentamentos precários, onde as condições materiais de existência das populações são tão ínfimas que as colocam, muitas vezes, abaixo da linha da pobreza" (ROBAINA; TRENTIN, 2013, p.28).

Outra característica que pode influenciar na vulnerabilidade está atrelada ao grau de conhecimento. Assim, o indicador alfabetização pode se constituir em uma 
premissa, o qual pressupõe que quanto mais alfabetizada, maiores chances de acesso aos canais e níveis de informação, podendo evitar riscos e perigos anunciados ou latentes dadas à carga de uso de determinado local. Desse modo, quanto menor o grau de alfabetização, maiores serão as chances da ocorrência de uma exposição maior ao perigo.

Ao observar os produtos cartográficos (Figuras 8AB), identifica-se que em alguns setores censitários a classe do fator de renda e da alfabetização se coaduna. É possível, ao avaliar a Figura 8A, ver a relação que se expressa da classe de alta e média renda estar localizada na área central e da classe de baixa renda nas áreas mais periféricas. Constata-se, também, que em alguns bairros próximos à área central se identificam os maiores índices de alfabetização em contraponto às áreas periféricas, com baixa alfabetização. Nesse sentido, os estudos de referência metodológica utilizada, a exemplo de Goerl et al. (2012) e de Robaina e Trentin (2013), trazem resultados que apontam claramente as áreas desiguais das cidades por eles estudadas, ou seja, as com menor e as com maior vulnerabilidade socioespacial e perigo de inundações. Reafirma-se, que a definição de tais áreas se torna uma ferramenta orientadora ao planejamento e à priorização de políticas públicas, sociais e de alcance de investimentos públicos.

Figura 8. Mapas dos indicadores socioespaciais:

A) Renda; B) Alfabetização; C) Densidade Demográfica; D) Tipologia (casa).

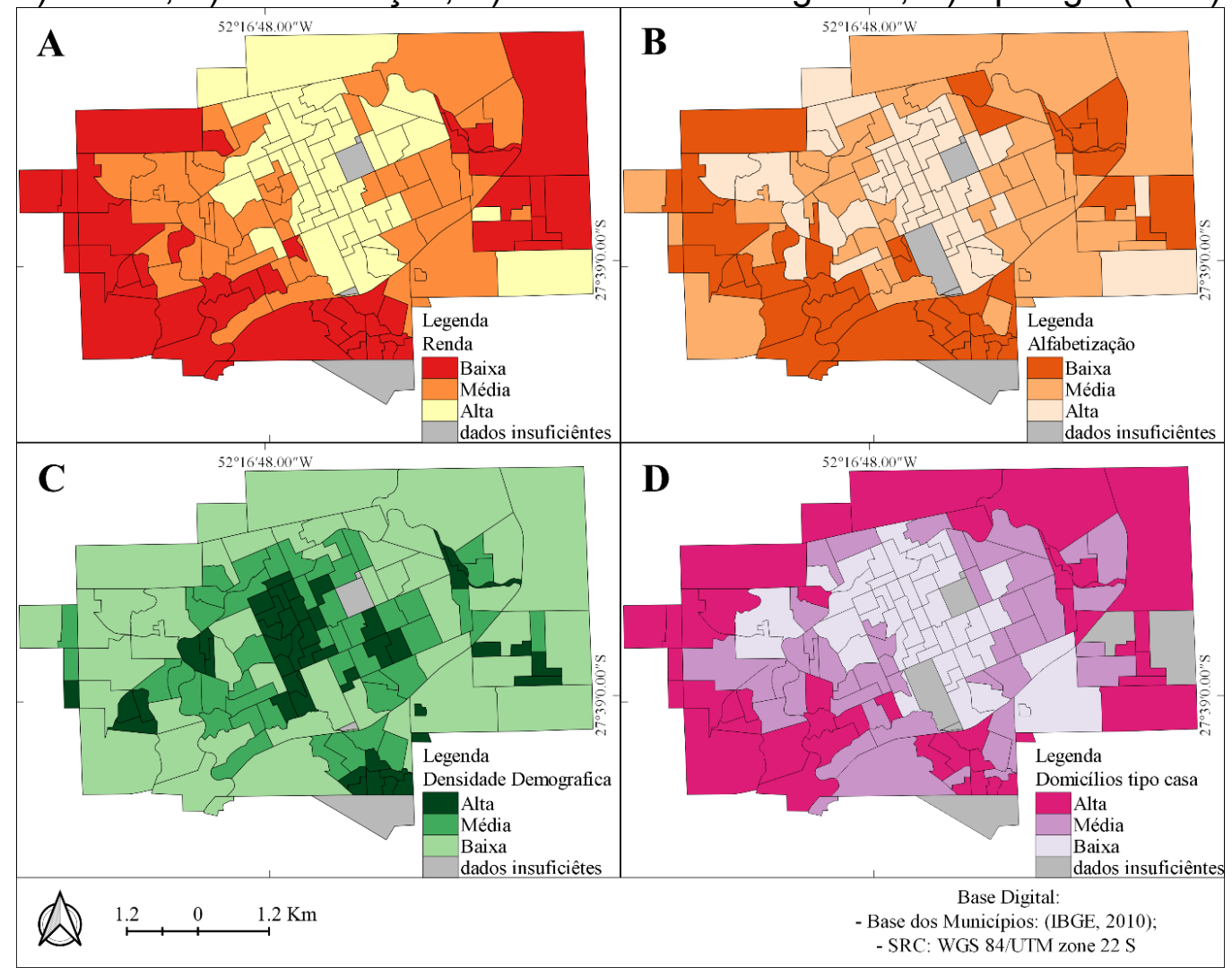

Fonte: Elaborado pelos autores, 2021

Ao verificar a "densidade populacional" (Figura $8 \mathrm{C}$ ), observa-se que ela apresenta alta em um grande conglomerado de setores na área central e em alguns setores mais afastados. A densidade demográfica de uma localidade influencia diretamente no impacto de eventos, como as inundações, pois quanto mais 
adensado, maior número de habitantes poderá ser atingido. A densidade demográfica também faz com que a população seja mais vulnerável, uma vez que nesses espaços tem-se maior número de pessoas envolvidas.

Por fim, outro ponto que caracteriza que a população se torne vulnerável é o padrão das construções, visto que construções precárias serão mais impactadas do que as com estrutura mais resistente. A variável "domicílios" tipo casa torna-se importante devido às questões estruturais, tendo em vista que esse padrão de moradia pode ser mais vulnerável a um evento que um prédio estruturado e com relativa previsão de redes de escoamento. A partir da relação e da visualização das Figuras $8 \mathrm{CD}$, identifica-se que a densidade alta ocorre na parte central e, também, em aglomerados de setores distribuídos em outras áreas. No entanto, a partir dos domicílios tipo casa, associando-se ainda à renda (Figura $8 \mathrm{~A}$ ) pode-se inferir sobre a localização de assentamentos precários. São nesses locais, que se constituem em áreas de forte adensamento de moradias que, em muitos casos, não há rede coletora pluvial e cloacal para tratamento, fator que agrava ainda mais os potenciais de alagamentos em eventos de alta precipitação.

Dessa forma, precisa-se evidenciar que a escolha das variáveis depende muito da área de estudo, no caso, acredita-se que essas variáveis apresentam resultados pertinentes. Tendo isso em conta, compreende-se que o conceito de vulnerabilidade é imprescindível para mensurar o potencial de perdas por parte da população envolvida com efeitos perigosos. Quanto aos bairros analisados nessa avaliação da vulnerabilidade por setor censitário, apresenta-se a síntese na Figura 9.

Figura 9. Mapa da vulnerabilidade por setor censitário

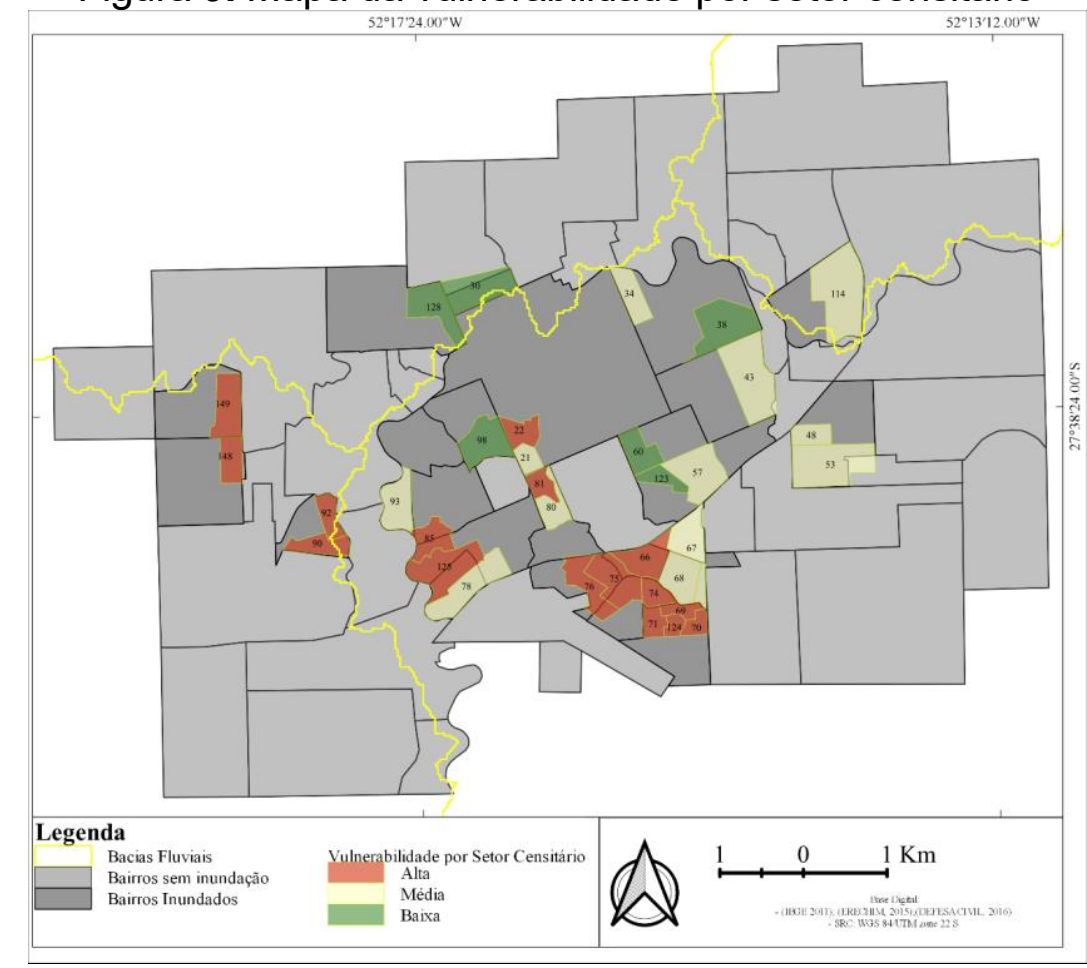

Fonte: Elaborado pelos autores, 2021

Dentre os 138 setores censitários, após o cruzamento dos dados, observouse que em 34 desses ocorrem processos de inundação, assim tendo 16 setores com vulnerabilidade Alta, 12 com vulnerabilidade Média e, por fim, 6 setores com 
vulnerabilidade Baixa. Considera-se, que a análise da vulnerabilidade deve estar presente quando ocorre a identificação dos processos geradores de perigo de inundação, pois é ela quem vai demonstrar qual é o potencial de perda a partir da ocorrência de um evento causador de perigo. Assim, tem-se que a vulnerabilidade está relacionada às condições que a população possui no enfrentamento, em relação a algum tipo de perigo. Por conseguinte, a vulnerabilidade está com forte tendência a aproximar-se da realidade socioeconômica de determinada população.

Analisando de maneira abrangente as bacias e setores censitários que possuem registros de inundação, observa-se que a bacia fluvial do Rio Dourado comporta dois bairros, o Ipiranga e o Dal Molin, contemplando dois setores, os quais demonstram que suas vulnerabilidades são baixas. Na bacia fluvial do Rio Suzana, tem-se apenas um bairro, o Copas Verdes, que contempla um setor, cuja vulnerabilidade é média e, também, destaca-se nesse setor a alfabetização baixa. A bacia fluvial do Rio Henrique comporta três bairros, Presidente Vargas, Paiol Grande e Cotrel e quatro setores, salienta-se que todos os setores apresentam vulnerabilidade alta, a renda de todos os setores é baixa e a maior porcentagem dos domicílios são do tipo casa (Quadro 3).

Quadro 3. Relação da vulnerabilidade.

\begin{tabular}{|c|c|c|c|c|c|c|c|}
\hline \multirow{2}{*}{$\begin{array}{l}\text { Bacia } \\
\text { Hidrográ- } \\
\text { fica }\end{array}$} & \multirow[b]{2}{*}{ Bairro } & \multirow[b]{2}{*}{ Setor } & \multicolumn{4}{|c|}{ Dados Sócio - Econômicos - Estruturais } & \multirow[b]{2}{*}{ Vulnerabilidade } \\
\hline & & & Renda & Alfabetização & $\begin{array}{c}\text { Densidade } \\
\text { demográfica }\end{array}$ & $\begin{array}{c}\text { Domicílios } \\
\text { tipo casa }\end{array}$ & \\
\hline \multirow{2}{*}{ Dourado } & Ipiranga & 30 & Alta (1) & Alta (1) & Baixa (1) & Média (2) & Baixa (5) \\
\hline & Dal Molin & 128 & Média (2) & Alta (1) & Baixa (1) & Média (2) & Baixa (6) \\
\hline Suzana & $\begin{array}{l}\text { Copas } \\
\text { Verdes }\end{array}$ & 114 & Média (2) & Baixa (3) & Baixa (1) & Média (2) & Média (8) \\
\hline \multirow{4}{*}{ Henrique } & \multirow{2}{*}{$\begin{array}{c}\text { Presidente } \\
\text { Vargas }\end{array}$} & 90 & Baixa (3) & Baixa (3) & Alta (3) & Alta (3) & Alta (12) \\
\hline & & 92 & Baixa (3) & Baixa (3) & Alta (3) & Alta (3) & Alta (12) \\
\hline & \multirow{2}{*}{$\begin{array}{l}\text { Paiol } \\
\text { Grande } \\
\text { Cotrel }\end{array}$} & 149 & Baixa (3) & Baixa (3) & Média (2) & Alta (3) & Alta (11) \\
\hline & & 148 & Baixa (3) & Média (2) & Média (2) & Alta (3) & Alta (10) \\
\hline \multirow{27}{*}{ Tigre } & \multirow{2}{*}{ Centro } & 22 & Média (2) & Média (2) & Alta (3) & Média (2) & Alta (10) \\
\hline & & 21 & Média (2) & Média (2) & Alta (3) & Média (2) & Média (9) \\
\hline & $\begin{array}{c}\text { Espírito } \\
\text { Santo }\end{array}$ & 98 & Média (2) & Alta (1) & Média (2) & Baixa (1) & Baixa (6) \\
\hline & \multirow{2}{*}{$\begin{array}{c}\text { São } \\
\text { Cristóvão }\end{array}$} & 80 & Média (2) & Baixa (3) & Alta (3) & Baixa (1) & Média (9) \\
\hline & & 81 & Baixa (3) & Baixa (3) & Alta (3) & Média (2) & Alta (11) \\
\hline & Koller & 93 & Média (2) & Alta (1) & Média (2) & Média (2) & Média (7) \\
\hline & Aldo Arioli & 85 & Baixa (3) & Baixa (3) & Média (2) & Alta (3) & Alta (11) \\
\hline & Cerâmica & 125 & Baixa (3) & Baixa (3) & Baixa (1) & Alta (3) & Alta (10) \\
\hline & Vitória II & 78 & Média (2) & Baixa (3) & Média (2) & Média (2) & Média (9) \\
\hline & São José & 66 & Baixa (3) & Baixa (3) & Média (2) & Alta (3) & Alta (11) \\
\hline & \multirow{2}{*}{$\begin{array}{c}\text { Pettit } \\
\text { Vilage }\end{array}$} & 67 & Média (2) & Baixa (3) & Baixa (1) & Média (2) & Média (8) \\
\hline & & 68 & Baixa (3) & Média (2) & Média (2) & Média (2) & Média (9) \\
\hline & Vitória I & 76 & Baixa (3) & Baixa (3) & Média (2) & Alta (3) & Alta (11) \\
\hline & \multirow{2}{*}{ Progresso } & 75 & Baixa (3) & Baixa (3) & Média (2) & Alta (3) & Alta (11) \\
\hline & & 74 & Baixa (3) & Baixa (3) & Alta (3) & Alta (3) & Alta (12) \\
\hline & \multirow{4}{*}{ Cristo Rei } & 69 & Baixa (3) & Baixa (3) & Alta (3) & Média (2) & Alta (11) \\
\hline & & 70 & Baixa (3) & Baixa (3) & Alta (3) & Alta (3) & Alta (12) \\
\hline & & 74 & Baixa (3) & Baixa (3) & Alta (3) & Alta (3) & Alta (12) \\
\hline & & 124 & Baixa (3) & Baixa (3) & Alta (3) & Alta (3) & Alta (12) \\
\hline & \multirow{3}{*}{ Bela Vista } & 57 & Média (2) & Média (2) & Média (2) & Média (2) & Média (8) \\
\hline & & 60 & Alta (1) & Alta (1) & Média (2) & Baixa (1) & Baixa (5) \\
\hline & & 123 & Alta (1) & Alta (1) & Média (2) & Média (2) & Baixa (6) \\
\hline & \multirow{2}{*}{$\begin{array}{c}\text { José } \\
\text { Bonifácio }\end{array}$} & 34 & Média (2) & Média (2) & Média (2) & Média (2) & Média (8) \\
\hline & & 38 & Alta (1) & Média (2) & Baixa (1) & Média (2) & Baixa (6) \\
\hline & Linho & 98 & Média (2) & Alta (1) & Média (2) & Baixa (1) & Baixa (6) \\
\hline & \multirow{2}{*}{ Atlântico } & 48 & Alta (1) & Média (2) & Alta (3) & Média (2) & Média (8) \\
\hline & & 53 & Baixa (3) & Média (2) & Baixa (1) & Média (2) & Média (8) \\
\hline
\end{tabular}

Fonte: Elaborado pelos autores, 2021 
As inundações na bacia fluvial do Rio Tigre atingem 16 bairros e a vulnerabilidade abrange 27 setores. Os setores do bairro Centro possuem vulnerabilidade alta e média, nesse setor, destaca-se a densidade demográfica alta por constituírem áreas de ocupação antiga e consolidada, em que principalmente no setor 21 teve presença de assentamentos sob canais fluviais, atualmente canalizados, que se fundem nessa área que é plana.

Outro aglomerado de setores censitários que também sofre com o problema de inundação, localiza-se no bairro Bela Vista e abrange três setores, em que um compreende a vulnerabilidade média e dois setores a vulnerabilidade baixa, conforme pode ser observado no Quadro 3. O último núcleo, em que ocorrem inundações, possui três bairros e cinco setores censitários. No bairro José Bonifácio, tem-se um setor com vulnerabilidade média e outro com vulnerabilidade baixa. $O$ bairro Linho possui vulnerabilidade baixa e o Atlântico apresenta dois setores que possuem vulnerabilidade média.

Esta análise comparada entre variáveis naturais e socioeconômicas ganha relevância por permitir alcançar ao poder público e órgãos locais de planejamento e gestão urbana, o (re)conhecimento de tais realidades e, assim, fornecer elementos técnicos e argumentos específicos à cada localidade para traçar diretrizes de ordenamento territorial. Tais diretrizes podem orientar a ocupação e o uso do solo nessas áreas, evitando outros danos. De outro lado, podem balizar a execução de medidas estruturais, com realização de obras de engenharia ou com a preservação do uso de áreas não adequadas à urbanização; além da cobrança da realização de obras necessárias por parte de loteadores/incorporadores, de forma a amenizar os problemas existentes ou evitá-los, no caso de novos loteamentos.

\section{CONSIDERAÇÕES FINAIS}

O presente estudo permitiu concluir que, na maioria dos casos, os fenômenos de inundação ocorrem em locais que sofreram interferências nos seus elementos naturais, como canalizações, ocupação de áreas planas e alterações no relevo. Os dados que compuseram a compreensão da vulnerabilidade foram contemplando os setores urbanos e foram cruzados de maneira a apresentar uma síntese do conjunto de análises. Após essa síntese, foram relacionados os pontos de ocorrência, sendo identificados em 34 setores. Algo que chama a atenção, é que a partir do cruzamento entre os dados observou-se que dos 34 setores identificados com problemas de inundações, a grande maioria apresentou-se com alta vulnerabilidade, demonstrando a validação da utilização das variáveis do censo, expostas no trabalho. Além disso, demonstra que a maior parte da ocorrência de fenômenos está relacionada às áreas com baixa alfabetização e renda, alta densidade demográfica e sobre domicílios tipo casa (das quais, muitas são precárias).

Dessa forma, pode-se evidenciar que os fenômenos ocorrem, em parte, devido à ação dos loteadores de terra, uma vez que ao elaborar os projetos para construção de loteamentos, não são levados em consideração os elementos naturais. O poder público, ao aprovar os loteamentos, também corrobora com essa não consideração. No decorrer da ocupação desses loteamentos, deflagra-se a ocorrência desses episódios, causando prejuízos tanto ao comprador do terreno, ao próprio poder público, que precisa buscar soluções para o problema, e, ainda, ao meio ambiente. Por isso a importância de que todo loteamento realizado deva passar por uma profunda avaliação. Nesse caso, se 
existe a liberação para a construção, o poder público, também, passa a ser corresponsável por eventuais riscos ou danos.

Em relação aos episódios hidrológicos, vale destacar a questão da ausência ou precariedade da rede de tratamento de esgoto, uma vez que, além da água invadir a residência durante as enchentes, traz diversos dejetos cloacais e industriais, fato que promove outros riscos à saúde da população. Dessa forma, o que se apresenta aqui é apenas um panorama recente da relação entre a área urbanizada de Erechim, e seus aspectos socionaturais. Logo, torna-se necessário destacar que o poder público deve ter atenção para a aprovação dos novos loteamentos, a fim de não ocorrer nessas novas áreas o que já vem acontecendo em áreas de ocupação mais antiga da cidade, bem como, buscar medidas mitigadoras para resolver os problemas de inundação em áreas recorrentes da cidade.

\section{REFERÊNCIAS BIBLIOGRÁFICAS}

ALMEIDA, L. Q; CARVALHO, P. F. Riscos naturais e sítio urbano - inundações na bacia hidrográfica do rio Maranguapinho, região metropolitana de Fortaleza, Brasil. Revista Brasileira de Geomorfologia, v.11, n.2, p.35-49, 2010.

ALMEIDA; L. Q de. Por uma ciência dos riscos e vulnerabilidades na geografia. Mercator, v. 10, n. 23, p. 83-99, set./dez. 2011.

AU Online - Portal de Notícias de Erechim/RS e Chapecó/SC. Disponível em: <https://auonline.com.br/home> acesso em 21 set. 2019.

AVER, I. K. Erechim, processo e projeto: relações estruturais entre traçado viário e desenvolvimento urbano. 2008. 151f. Dissertação (Mestrado em Planejamento Urbano e Regional) - Universidade Federal do Rio Grande do Sul, Faculdade de arquitetura. Porto Alegre, 2008.

COELHO NETTO, A. L; AVELAR, A de. S. O uso da terra e a dinâmica hidrológica comportamento hidrológico e erosivo de bacias de drenagem. In: SANTOS, R. F (org.). Vulnerabilidade ambiental: Desastres naturais ou fenômenos induzidos?. Brasília: MMA, 2007. p.65-73.

CUNHA, L; RAMOS, A. M. Riscos naturais em Portugal: alguns problemas perspectivas e tendências no estudo dos riscos geomorfológicos. In: LOMBARDO, M. A; FREITAS, M. I. C. de (Org.). Riscos e vulnerabilidade: teoria e prática no contexto luso-brasileiro. São Paulo: Cultura Acadêmica, 2013. p. 19-44.

CUTTER, S. L. A ciência da vulnerabilidade: Modelos, métodos e indicadores. Revista Crítica de Ciências Sociais, nº 93, p 59-69, 2011.

FURLAN, A. R. Urbanização e Riscos Socioambientais em Erechim - RS. 2016. Trabalho de Conclusão de Curso (Geografia - Licenciatura) Universidade Federal da Fronteira Sul, Erechim, 2016. 
FURLAN, A. R.; SPINELLI, J. Urbanização em áreas de risco e desigualdades socioambientais: um estudo a partir da relação sociedade/natureza no grande Bairro Progresso, Erechim, RS. GEOINGÁ, v. 8, p. 180-199, 2016.

GOERL, R. F; KOBIYAMA, M; PELLERIN, J. R. G. M. Proposta metodológica para mapeamento de áreas de risco a inundação: estudo de caso do município de rio negrinho - SC. Boletim Geografia, v. 30, nº 1, p. 81-100, 2012.

GONZALEZ, D; COSTA, A. da. Análise da percepção de risco e vulnerabilidade a partir dos alunos do ensino médio na vivência de Nova Friburgo RJ após desastre natural de 2011. Revista de Geografia e Ordenamento do Território, v.1, n. ${ }^{\circ}$ 9, p. 187-211, 2016.

IBGE - INSTITUTO BRASILEIRO DE GEOGRAFIA E ESTATÍSTICA. Base de informações do Censo Demográfico 2010: Resultados do Universo por setor censitário. Rio de Janeiro: IBGE, 2011.

IBGE - INSTITUTO BRASILEIRO DE GEOGRAFIA E ESTATÍSTICA. Séries Históricas e Estatísticas 2009: Disponível em <https://seriesestatisticas.ibge.gov.br/apresentacao.aspx>, acesso em 21 out. 2019.

MENDONÇA, F. et al. Resiliência socioambiental-espacial urbana à inundações: possibilidades e limites no bairro Cajuru em Curitiba (PR). Revista da ANPEGE, v.12, n. 19, p.279-298, 2016.

NUNES, L. H. Urbanização e produção de risco aos desastres naturais: exemplos da América do Sul. In: LOURENÇO, L, F; MATEUS, M. A. (Org.). Riscos Naturais, antrópicos e mistos. Homenagem ao Professor Dr. Fernando Rebelo. 1ed. Coimbra: Simões \& Linhares, Ltda., 2013, v. 1, p. 181-196.

2015.

. Urbanização e desastres naturais. São Paulo: Oficina de textos,

PERETTI, V. A. Análise espaço-temporal dos desastres naturais no município de Erechim - RS, no período de 1986 a 2011. 2013. 101f. Dissertação (Mestrado em Geografia) - Universidade Federal de Santa Maria, Curso de Mestrado do Programa de Pós-Graduação em Geografia e Geociências, Santa Maria, 2013.

RECKZIEGEL, B. W. Levantamento dos Desastres Desencadeados por Eventos Naturais Adversos no Estado do Rio Grande do Sul no Período de 1980 a 2005. 2007. Dissertação (Mestrado em Geografia) - Universidade Federal de Santa Maria, Curso de Mestrado do Programa de Pós-Graduação em Geografia e Geociências, Santa Maria, 2007.

ROBAINA, L. E de. S; TRENTIN, R. Áreas de risco por processos de dinâmica geomorfológica no Rio Grande do Sul: fundamentos e conceitos. GEOGRAFIA, Rio Claro, v. 38, n. 3, p. 589-607, set./dez. 2013. 
SAITO, S. M. Desastres naturais e geotecnologias vulnerabilidade. Caderno didático, 2011, $\mathrm{n}^{\circ}$. 6. Disponível em: <http://mtc-m16d.sid.inpe.br/col/sid.inpe.br/mtcm19/2011/11.16.18.05/doc/publicacao.pdf > Acesso em: 11 set. 2014.

SANTOS, J. de O. Relações entre fragilidade ambiental e vulnerabilidade social na susceptibilidade aos riscos. Mercator, Fortaleza, v. 14, n. 2, p. 75-90, 2015.

TUCCI, C. E. M. Inundações e drenagem urbana. In: TUCCI, C. E. M; BERTONI, J. $C$ (Org.). Inundações Urbanas na América do Sul. 1. ed. Porto Alegre: ABRH, GWP, WMO, 2003. p. 45-156. 